\title{
A serological survey of agents causing leptospirosis and toxoplasmosis in Rattus rattus in the city of Umuarama, northwest Paraná, Brazil
}

\section{Inquérito sorológico de agentes causadores de leptospirose e toxoplasmose em Rattus rattus da cidade de Umuarama, Noroeste do Paraná, Brasil}

\author{
Karoline Franciani Cardoso Lopes ${ }^{1}$; Ricardo de Melo Germano ${ }^{2}$; \\ Edson Gerônimo ${ }^{1}$; Danila Zago ${ }^{3}$; Eduardo Herrera Dias ${ }^{4}$; \\ Roberta Torres Chideroli5; Fernanda Evers ${ }^{6}$; Italmar Teodorico Navarro ${ }^{7}$; \\ Julio Cesar de Freitas ${ }^{7}$; Daniela Dib Gonçalves ${ }^{8^{*}}$
}

\begin{abstract}
Synanthropic rodents, present in both urban and rural areas, are responsible for the zoonotic transmission of several diseases to humans as well as for significant economic losses. They act as reservoirs for important viral diseases, bacterial diseases such as leptospirosis, and parasitic diseases such as toxoplasmosis and leishmaniasis. The aim of the present study was to assess the seropositivity of synanthropic rodents in Umuarama city, located in the northwestern region of Paraná State, Brazil, to agents causing leptospirosis and toxoplasmosis. The microscopic agglutination technique (MAT) was used to detect anti-Leptospira antibodies, and the indirect immunofluorescence reaction (IIFR) was used to detect anti-Toxoplasma gondii antibodies. Of 178 animals collected, four $(2.24 \%)$ were seropositive for Leptospira spp. and ten (5.62\%) for Toxoplasma gondii. Ninety-five $(53.38 \%)$ of the collected animals were male and $83(46.62 \%)$ were female, and two $(1.23 \%)$ originated from urban areas while $176(98.87 \%)$ originated from peri-urban areas. Serological results showed that the synanthropic rodents examined here had low seroreactivity for agents causing both leptospirosis and toxoplasmosis, in both urban and peri-urban regions of Umuarama city. This could be associated with the high Human Development Index for the study area. However, preventative measures must continue to be observed, as rodents are important reservoirs for, and disseminators of, disease causing agents.
\end{abstract}

Key words: Leptospira spp. Rats. Serological diagnosis. Toxoplasma gondii. Zoonosis.

\footnotetext{
${ }^{1}$ Biólogos, Discentes do Doutorado em Ciência Animal com Ênfase em Produtos Bioativos, Universidade Paranaense, UNIPAR, Umuarama, PR, Brasil. E-mail: karol_.lopes@hotmail.com; geronimoedson@yahoo.com.br

2 Biólogo, Prof. Dr., Programa de Pós-Graduação em Ciência Animal com Ênfase em Produtos Bioativos, Universidade Paranaense, UNIPAR, Umuarama, PR, Brasil. E-mail: germano@unipar.br

${ }^{3}$ Tecnóloga de Alimentos, Prof ${ }^{a}$ M.e, Colégio Agrícola Estadual de Umuarama, Umuarama, PR, Brasil. E-mail: zagodanila@ hotmail.com

${ }^{4}$ Discente de Graduação em Medicina Veterinária, Universidade Estadual de Maringá, UEM, Umuarama, PR, Brasil. E-mail: eduhd_herreradias@hotmail.com

${ }^{5}$ Médica Veterinária, Discente do Doutorado em Ciência Animal, Universidade Estadual de Londrina, UEL, Londrina, PR, Brasil. E-mail: robertaa_tc@hotmail.com

${ }^{6}$ Médica Veterinária, Prof ${ }^{\mathrm{a}} \mathrm{Dr}^{\mathrm{a}}$, Centro Universitário Filadélfia, UniFil, Londrina, PR, Brasil. E-mail: fervet.76@hotmail.com

7 Médicos Veterinários, Profs. Drs., Programa de Pós-Graduação em Ciência Animal, Universidade Estadual de Londrina, UEL, Londrina, PR. E-mail: italmar@uel.br; freitasj@uel.br

${ }^{8}$ Médica Veterinária, Prof ${ }^{a}$ Dra $^{a}$, Programa de Pós-graduação em Ciência Animal com Ênfase em Produtos Bioativos, UNIPAR, Umuarama, PR, Brasil. E-mail: danieladib@unipar.br

* Author for correspondence
} 


\section{Resumo}

Os roedores sinantrópicos determinam grandes prejuízos econômicos, e são responsáveis pela transmissão de várias zoonoses ao homem tanto em áreas urbanas quanto nas rurais, atuando como reservatórios de importantes doenças que incluem a leptospirose, toxoplasmose, leishmaniose e algumas de etiologia viral. O presente trabalho investigou a sororeatividade para leptospirose e toxoplasmose em roedores sinantrópicos da cidade de Umuarama, cidade localizada na região noroeste do estado do Paraná, Brasil. A técnica Soroaglutinação Microscópica (SAM) foi utilizada para a detecção de anticorpos anti-Leptospira spp e a Reação de Imunofluorescência Indireta (RIFI) para a detecção de anticorpos anti-Toxoplasma gondii. Dos 178 animais examinados, quatro $(2,24 \%)$ foram reagentes para Leptospira spp. e $10(5,62 \%)$ para o Toxoplasma gondii. Destes animais, $95(53,38 \%)$ eram machos e $83(46,62 \%)$ fêmeas, dois $(1,23 \%)$ eram provenientes da área urbana e $176(98,87 \%)$ da área periurbana. Os resultados obtidos demonstraram que os roedores sinantrópicos examinados apresentaram baixa freqüência de sororeatividade para as duas zoonoses investigadas, tanto na região urbana como na periurbana da cidade de Umuarama, fato que pode estar associado ao alto Índice de Desenvolvimento Humano encontrado, contudo, as medidas preventivas devem ser mantidas, pois os roedores são importantes elos na cadeia epidemiológica das doenças analisadas.

Palavras-chave: Diagnóstico sorológico. Leptospira spp. Ratos. Toxoplasma gondii. Zoonoses.

\section{Introduction}

Synanthropic rodents, present in both urban and rural areas, are responsible for the zoonotic transmission of several diseases to humans as well as for significant economic losses. They act as reservoirs for important viral diseases, bacterial diseases such as leptospirosis, and parasitic diseases such as toxoplasmosis and leishmaniasis. Control of these rodents is therefore considered important for public health. As humans have invaded or destroyed their natural habitat these animals have undergone a synanthropic process, which has increased their contact with humans and thus the risk of disseminating the diseases they harbor (BRASIL, 2002; FAINE et al., 1999; GERÔNIMO et al., 2014; PORTA et al., 2014).

Rodents are important reservoir hosts for Leptospira spp., and disseminate the etiological agent through contaminated urine, water, soil, and food. Additionally, they increase the susceptibility of human beings and other animal species to further Leptospira infection (BRASIL, 2002, 2010a; LEVETT, 2001; MORIKAWA, 2010).

Leptospirosis is a broadly disseminated, contagious disease that is thought to be one of the most widespread zoonotic diseases worldwide
(PALANIAPPAN et al., 2007). In recent decades this disease has been widely neglected, in large part because its symptoms are nonspecific and easily confused with those of other diseases, such as influenza, leading to incorrect diagnoses and fewer notifications (HARTSKEERL et al., 2011; SOCOLOVSCHI et al., 2011). However, leptospirosis is considered to be a re-emergent disease with serious public health implications (HARTSKEERL et al., 2011).

The prevalence of leptospirosis in rodents, as determined by the level of antibodies raised in response to different serovars, ranges from $3.33 \%$ to $30.2 \%$ in different countries (AGUDELO-FLÓREZ et al., 2009; FELT et al., 2011; GAROUSSI et al., 2006; HALLIDAY et al., 2013; MARTINS; LILENBAUM, 2013; MGODE et al., 2014; MOHAMED et al., 2010; SPOHR, 2009; WANG; HE, 2013). In Brazil, leptospirosis positivity rates of $9.3 \%$ and $17 \%$ were detected in Paraná (PR) (SPOHR, 2009) and Rio de Janeiro (MARTINS; LILENBAUM, 2013), respectively.

Leptospirosis is not the only disease transmitted by rodents. In some cases, rodents infect other animal species, which then become definitive hosts and disseminators of the infectious agent. 
This is evident in the case of toxoplasmosis, a disease caused by Toxoplasma gondii (T. gondii), which infects mammals, birds, and warm-blooded vertebrates (HERRMANN et al., 2012). Rodents participate in the chain of infection by acting as the source of infection for several animal species, mainly felines, which become definitive hosts for T. gondii (COLA et al., 2010; DUBEY; FRENKEL, 1998; HERRMANN et al., 2012).

The seroreactivity of rodents to $T$. gondii has been investigated in several countries, with seropositivity ranging from $1.96 \%$ to $27.50 \%$ (COLA et al., 2010; JITTAPALAPONG et al., 2011; MERCIER et al., 2013; RUFFOLO, 2008; VUJANIĆ et al., 2011). In Paraná, Brazil, $8.80 \%$ and $4.94 \%$ seropositivity to T. gondii was reported by Ruffolo (2008) and Cola et al. (2010), respectively.

Considering the absence of regional data and the importance of rats as transmitters of infectiousparasite diseases to humans and also other animal species, the purpose of this paper was to assess the seroreactivity to leptospirosis and toxoplasmosis in synanthropic rodents in the city of Umuarama, in the Northwestern Mesoregion of the State of Paraná, Brazil.

\section{Material and Methods}

Study area

Synanthropic rodents were captured in the urban and peri-urban areas of Umuarama city (2345'59's; 5319’30'W), and blood samples were collected. This region has an average altitude of $442 \mathrm{~m}$ and an area of $1232.5 \mathrm{~km}^{2}$, and is located in the northwestern mesoregion of Paraná state (IPARDES, 2012).

\section{Rodent Capture and Sample Preparation}

The rodents were captured between October 2012 and October 2013, using galvanized wire traps (Tomahawk) measuring either 30x14x14cm or $45 \times 22 \times 22 \mathrm{~cm}$ in which the triggering mechanism was activated by placing bait within the trap. The baits used were raw corn, banana, sausage, cheese, and feed based on sardines, peanuts, corn flour, and banana, which was invented by the project researchers. The traps were assembled in the evening at locations where the presence of rodents was indicated by feces, trails, or fat stains, and were then collected the following morning (ARAUJO et al., 2010; RUFFOLO, 2008). The captured rodents were then transported to the Laboratory of Preventive Veterinary Medicine and Public Health at the Universidade Paranaense, Brazil, for investigation.

The rodents were desensitized in a halothanesaturated vapor chamber (ARAUJO et al., 2010), identified using the criteria described in the Manual for Rodent Control (Manual de Controle de Roedores, BRASIL, 2002), and guillotined. Blood samples were centrifuged at $1500 \mathrm{rpm}$ for 10 minutes, and the sera were aspirated, transferred to $2 \mathrm{ml}$ tubes, and stored at $-20^{\circ} \mathrm{C}$ until use.

\section{Diagnostic Tests}

\section{Microscopic Seroagglutination test (MAT)}

Anti-Leptospira spp. antibodies in the serum samples were measured at the Laboratory of Leptospirosis, the Department of Preventive Veterinary Medicine (DMVP), the State University of Londrina (UEL), using a MAT assay with live leptospires as antigens. Twenty-three reference Leptospira serovars were used: Australis, Bratislava, Autumnalis, Butembo, Castellonis, Bataviae, Canicola, Whitcomb, Cynopteri, Fortbragg, Grippotyphosa, Hebdomadis, Copenhageni, Icterohaemorrhagiae, Panama, Pomona, Pyrogenes, Hardjo, Wolffi, Shermani, Sentot, Tarassovi, and Ballum. Leptospires were maintained at $28{ }^{\circ} \mathrm{C}$ for 5-10 days in Difco ${ }^{\mathrm{TM}}$ Leptospira Enrichment 
medium (EMJH, DIFCO ${ }^{\circledR}$-USA $)^{9}$ supplemented with rabbit serum (ALVES, 1996). Rat serum samples were serially diluted to 1:25 for use in the MAT assay (RIEDEMANN et al., 1994; SPORH, 2009).

Sera that agglutinated at least $50 \%$ of the leptospires were considered seropositive. Two-fold serial dilutions of positive samples were tested in order to determine the titer (the maximum dilution that gave a seropositive result). The serovar with the highest titer was considered dominant for that sample (VASCONCELLOS et al., 1997). In serum samples where more than one serovar presented the highest titer, Leptospira spp. was considered dominant (ALMEIDA et al., 1994).

\section{Indirect Immunofluorescence Reaction (IIFR)}

The IIFR technique was performed at the Laboratory of Zoonoses and Public Health, DMVP, UEL, as described by Camargo (1973). The sera were serially diluted four-fold, starting from a 1:16 dilution, until the maximum titer was reached. Samples with a titer greater than or equal to 16 were considered seropositive.

\section{Results}

A total of 178 rodents of various ages were captured, and all were identified as Rattus rattus. Of these, 95 (53.38\%) were male and 83 (46.62\%) were female, and $2(1.23 \%)$ originated from urban areas while the remaining $176(98.87 \%)$ originated from peri-urban areas.

Four of the 178 samples were determined by MAT assay to be seropositive for leptospires, with antibodies against the following serovars

9 DIFCO - Becton, Dickinson and Company 7 Loveton Circle Sparks, MD 21152 USA 800-638-8663 www.bd.com/ ds ATCC is a trademark of the American Type Culture Collection. Difco is a trademark of Difco Laboratories, Inc., subsidiary of Becton, Dickinson and Company. BD and BD Logo are trademarks of Becton, Dickinson and Company. (C) 2011 BD. being detected at a 1:25 dilution: Hardjo (2/4), Copenhageni (1/4), and Pyrogenes (1/4). Two $(50 \%)$ of the seropositive rats were male, and two $(50 \%)$ were female.

Ten of the 176 samples were determined by IIFR assay to be seropositive for toxoplasmosis, with titers of $16(7 / 10), 64(2 / 10)$ or $1024(1 / 10)$. Of these ten rats, eight were male and two were female.

\section{Discussion}

Previous studies that aimed to understand the epidemiology of leptospirosis and toxoplasmosis identified anti-Leptospira spp. and anti-T. gondii antibodies in rodents from different worldwide locations (COLA et al., 2010; HALLIDAY et al., 2013; JITTAPALAPONG et al., 2011; MARTINS; LILENBAUM, 2013; MERCIER et al., 2013; MGODE et al., 2014; RUFFOLO, 2008; SPOHR, 2009; VUJANIĆ et al., 2011; WANG; HE, 2013).

When human beings settle in a defined location and develop their own infrastructure and living conditions, commensal relationships develop between humans and rodents, and synanthropic processes are initiated (BRASIL, 2002). In urban centers, deficiencies in basic sanitation are critical factors in the dissemination of rodents and, consequently, the dissemination of zoonoses that use rodent hosts during their epidemiological cycle (MORIKAWA, 2010).

The seropositivity of synanthropic rodents for leptospires reported here, $2.27 \%$, was lower than that reported previously, wherein $R$. rattus in Londrina (PR) (SPOHR, 2009) and Rattus norvegicus in Rio de Janeiro (MARTINS; LILENBAUM, 2013) had seropositivity rates of $9.3 \%$ and $36.2 \%$, respectively, for anti-Leptospira spp. antibodies. These serological differences might reflect differences in the seroreactivity of animal leptospirosis in the respective locations, or differences in the study length, with infection being less likely in a shorter study period. 
The low prevalence of leptospirosis observed here could be due to multiple factors, including periods of hydric deficiency (ROSEGHINI et al., 2000), and the prevalence of soil containing more than $70 \%$ sand in the northwestern region of Paraná state where the study takes place. This soil composition is the reason for the local name for the region - Arenito Caiuá, or Sandstone Caiuá (EMBRAPA, 2006). Such sandy soil is very water permeable and thus very dry as water quickly dissipates, which could impede the survival of Leptospira, as these organisms require humidity for the maintenance of active infection in animals (DREER, et al. 2013; FAINE et al., 1999).

The most prevalent serovar in this study was the Hardjo serovar, which was present in $50 \%$ of the samples. The antibody against this serovar was raised in cattle (MINEIRO et al., 2007). There is only a short distance between the perimeter of the peri-urban region where the rodents were captured and some rural properties, and the people and animals residing in these properties are susceptible to infection. Individuals working directly with animals, such as farmers, veterinarians, rural workers, and slaughterhouse workers, can reportedly acquire leptospiral infection through contact with contaminated urine, milk, aborted fetuses, carcasses, or placentas (WASIŃSKI; DUTKIEWICZ, 2013; GONÇALVES et al., 2013). Indeed, Clazer (2016), studied the same micro-region as this study and observed the presence of antibodies against the Hardjo serovar in the sera of $50 \%$ of university students enrolled on a veterinary medicine course.

In a report published in 2016 by Brazil's Ministry of Health (BRASIL, 2016), the Copenhageni serovar was associated with the most severe human cases of leptospirosis. A wide variety of susceptible animals can host this serovar (FORSTER et al., 2013; LANGONI et al., 2016; RODRIGUES et al., 2015). Maciel et al. (2008) investigated seropositivity to the Copenhageni serovar in 269 residents of peripheral neighborhoods in the city of Salvador in Bahia, Brazil, and found that $30 \%$ were seropositive, with titers ranging from 25 to 400. Additionally, a study of bacteria isolated from the sera of ten sick individuals as well as rodents in the São Miguel parish of Lisbon showed that $70 \%$ were seropositive for the Leptospira interrogans species of the Copenhageni serovar (GONÇALVES, 2009). Additionally, a further study investigating $R$. rattus in a peripheral neighborhood of Barranquila, Columbia, described the presence of the Copenhageni serovar and noted that, while infection did not present as an acute condition in rodents, the animals could act as reservoirs, leading to more severe infection in humans (ROMEROVIVAS et al., 2013).

The first report of seropositivity to the Pyrogenes serovar in Brazil was in 1980, in sera from Nectomys squamipes, a wild mammalian species (SANTA ROSA et al., 1980). This serovar is now routinely included in serological assays for infection with Leptospira for several animal species, and recent studies have shown its prevalence in goats and sheep (HIGINO; AZEVEDO, 2014), dogs (FONZAR; LANGONI, 2012; MASCOLLI et al., 2016; SAMIR et al., 2015), and humans (FONZAR; LANGONI, 2012; SAMIR et al., 2015; BRASIL, 2010b).

The Copenhageni and Pyrogenes serovars detected in this study can reportedly infect humans (GONÇALVES, 2009; FONZAR; LANGONI, 2012). In Brazil, there were 1,827 deaths from leptospirosis between 2011 to 2016 according to the National Medical Service System (SINAM, c2016), and so epidemiological studies to investigate patterns of infection and establish the dominant causative serovars are crucial for disease prevention and public health education measures.

In 2013, Dreer et al., reported a 20\% seroprevalence of anti-Leptospira spp. antibodies in stray dogs in Umuarama city, a higher prevalence than is reported in this study, demonstrating the importance of stray dogs as probable sources of infection for other domestic animal species as well as rodents. It is also important to emphasize that 
antibodies against the same serovars (Hardjo \& Pyrogenes) were detected in stray dogs by Dreer et al. (2013) and in rodents in this study.

Considering toxoplasmosis, cats are considered to be definitive hosts for the infection, and are thought to contract the disease by ingesting the sporulated $T$. gondii oocysts that are usually present in the intestinal villi of infected rodents (PIZZI, 1997). Once infected, cats can eliminate approximately 360 million oocysts in a single day. Such oocysts are extremely resistant to harsh environments and can sporulate, allowing them to survive in water for several months. Stray cats are therefore critical to the epidemiological cycle of the disease (ARAUJO et al., 2010; DUBEY; FRENKEL, 1998; PINTO et al., 2009).

In this study, $5.68 \%$ of the samples analyzed were seropositive for $T$. gondii, a higher proportion than was detected by Cola et al. (2010) in Londrina (PR) (4.94\%), Mgode et al. (2014) in Dar es Salaam, Tanzania (2.17\%), and Mercier et al. (2013) in Niamey, Nigeria (1.96\%).

The epidemiological impact of toxoplasmosis makes this disease a significant public health concern. Transmission of $T$. gondii to humans can occur via congenital infection or through the ingestion of cysts in undercooked meat or oocysts in contaminated water (ABREU et al., 2001; CLAZER, 2016). Clazer (2016) reported a T. gondii seroprevalence of $29.29 \%$ in humans. This is in contrast to the $5.68 \%$ seroprevalence in rodents reported here, even though the two studies considered the same geographical region. It is therefore possible to incorporate both species into the epidemiological disease cycle in this region, with rodents being potential disseminators of the disease.

Other important sources of $T$. gondii transmission are contaminated water and meat. From December 2001 to January 2002, an outbreak occurred in the city of Santa Isabel do Ivaí (PR) when a water reservoir became contaminated with the protozoan, most likely through contaminated cat urine (ALMEIDA et al., 2011). This led to the conclusion that the water supply system was particularly vulnerable to protozoan oocytes contamination. This city is located just $117 \mathrm{~km}$ from the city of Umuarama, and thus belongs to the same mesoregion that was considered in the present study. Furthermore, the ingestion of tissue cysts in meat from infected animals, either by humans eating undercooked meat or by carnivorous animals, can contribute to disease spread. In this case, rodents are an important part of the disease cycle.

The region studied in this report, particularly the city in which the rodents were captured, had one of the highest human development index for municipalities (HDI-M) scores in the northwestern mesoregion of Paraná from 2000 to 2010 (TOMÉ; LIMA, 2014). During this period, longevity, income, and education significantly improved, leading to consequent improvements in lifestyle and health. The quality of sanitation improved concurrently with the human development index, reducing the dissemination of the zoonotic diseases analyzed and thus the potential for exposure, which could be a factor in the lower prevalence of both Leptospira and $T$. gondii in rodents in the study region.

\section{Conclusion}

The rates of infection with the agents causing leptospirosis and toxoplasmosis recorded in the study region were lower than the expected rate, due to unfavorable soil composition and programs for the collection of stray animals reducing the potential for dissemination. Synanthropic rodents, which act as natural reservoirs for a variety of zoonoses, presented a low seroprevalence for Leptospira and T. gondii in both the urban and peri-urban regions of Umuarama city. This low prevalence could be associated with zoo-sanitary measures, but action to prevent disease dissemination must continue to be observed, as rodents are known to be reservoirs for the agents causing these diseases. 
Few studies investigating leptospirosis, toxoplasmosis, or other infectious parasitic diseases in rodents have been published, as capturing these animals is difficult. For this reason, further studies into the infection of rodents with pathogenic agents are vital for a full understanding of their role in zoonotic transmission in a given geographical area.

\section{Ethics Committee}

Animals were captured and handled according to the principles established by the National Council for the Control of Animal Experimentation (CONCEA). The study was approved by the Ethics Committee in Research Involving Animal Experimentation (CEPEEA) at the Universidade Paranaense (UNIPAR, project protocol no. 21822/2012).

\section{Acknowledgments}

The authors would like to thank UNIPAR for funding this research.

\section{References}

ABREU, C. B. de; NAVARRO, I. T.; BALARIN, M. R. S.; BRACARENSE, A. P. F. R. L.; MARANA, E. R. M.; TRAPP, S. M.; FUGINAKA, C. A.; PRUDÊNCIO, L. B.; MATOS, M. R.; TSUTSUI, V. S. Aspectos clínicos, patológicos e sorológicos da toxoplasmose experimental em cães jovens. Semina. Ciências Agrárias, Londrina, v. 22, n. 2, p. 123-130, 2001.

AGUDELO-FLÓREZ, P.; LONDOÑO, A. F.; QUIROZ, V. H.; ÁNGEL, J. C.; MORENO, N.; LOAIZA, E. T.; MUÑOZ, L. F.; RODAS, J. D. Prevalence of Leptospira spp. in urban rodents from a groceries trade center of Medellin, Colombia. The American Journal of Tropical Medicine and Hygiene, Balitmore, v. 81, n. 5, p. 906-910, 2009.

ALMEIDA, L. P.; MARTINS, L. F. S.; BROD, C. S.; GERMANO, M. L. Levantamento soroepidemiológico de leptospirose em trabalhadores do serviço de saneamento ambiental em localidade urbana da região sul do Brasil. Revista de Saúde Pública, São Paulo, v. 28, n. 1, p. 7681, 1994.
ALMEIDA, M. J. de; OLIVEIRA, L. H. H.; FREIRE, R. L.; NAVARRO, I. T. Aspectos sociopolíticos da epidemia de toxoplasmose em Santa Isabel do Ivaí (PR). Ciência \& Saúde Coletiva. Rio de Janeiro, v. 16, p. 1363-1373, 2011. Suplemento 1.

ALVES, C. J.; VASCONCELLOS, S. A; CAMARGO, C. R. A.; MORAIS, Z. M. Influência de fatores ambientais sobre a proporção de caprinos soro reatores para a leptospirose em cinco centros de criação do estado da Paraíba, Brasil. Arquivos do Instituto Biológico, São Paulo, v. 63, n. 2, p. 11-18, 1996.

ARAUJO, J. B.; SILVA, A. V. da; ROSA, R. C.; MATTEI, R. J.; SILVA, R. C. da; RICHINI-PEREIRA, V. B.; LANGONI, H. Isolation and multilocus genotyping of Toxoplasma gondii in seronegative rodents in Brazil. Veterinary Parasitology, Chichester, v. 174, n. 3-4, p. 328-331, 2010.

BRASIL. Ministério da Saúde. Fundação Nacional da Saúde. Manual de controle de roedores. Brasília: Ministério da Saúde, 2002. 132 p.

Ministério da Saúde. Leptospirose: informações técnicas. Brasília: Portal da Saúde, c2016. Não paginado. Disponível em: <http://portalsaude.saude.gov.br/index. php/informacoes-tecnicas>. Acesso em: 27 jul. 2016.

Ministério da Saúde. Secretaria de Vigilância Epidemiológica. Guia de vigilância epidemiológica. 7. ed. Brasília: Ministério da Saúde, 2010a. 816 p.

Secretaria de Vigilância em Saúde, Ministério da Saúde. Investigação do surto de Leptospirose no município de Pacoti, Ceará, em 2009. Brasília: Ministério da Saúde, 2010b. v. 10, n. 9, 4 p. Disponível em: <http://u. saude.gov.br/images/pdf/2015/fevereiro/23/boletim-epin9-dez2010-.pdf>. Acesso em: 17 ago. 2016.

CAMARGO, M. E. Introdução às técnicas de imunofluorescência. Revista Brasileira de Patologia Clínica, Rio de Janeiro, v. 10, n. 4, p. 143-171, 1973.

CLAZER, M. Soroepidemiologia da Toxoplasmose, Leptospirose e Brucelose em acadêmicos de medicina veterinária e sua relação com a saúde única. 2016. Dissertação (Mestrado em Ciência Animal) Universidade Paranaense, Umuarama.

COLA, G. A.; GARCIA, J. L.; COSTA, L. da; RUFFOLO, B.; NAVARRO, I. T.; FREIRE, R. L. Comparação da reação de imunofluorescência indireta e do teste de aglutinação modificado na detecção de anticorpos antiToxoplasma gondii em ratos. Semina: Ciências Agrárias, Londrina, v. 31, n. 3, p. 717-722, 2010. 
DREER, M. K. P.; GONÇALVES, D. D.; CAETANO, I. C. S.; GERÔNIMO, E.; MENEGAS, P. H.; BERGO, D.; LOPES-MORI, F. M. R.; BENITEZ, A.; FREITAS, J. C. de; EVERS, F.; NAVARRO, I. T.; MARTINS, L. A. Toxoplasmosis, leptospirosis and brucellosis in stray dogs housed at the shelter in Umuarama municipality, Paraná, Brazil. Journal of Venomous Animals and Toxins including Tropical Diseases, Botucatu, v. 19, n. 1, p. 1-5, 2013.

DUBEY, J. P.; FRENKEL, J. K. Toxoplasmosis of rats: a review, with considerations of their value as an animal model and their possible role in epidemiology. Veterinary Parasitology, Chichester, v. 77, n. 1, p. 1-32, 1998.

EMPRESA BRASILEIRA DE PESQUISA AGROPECUÁRIA - EMBRAPA. Sistema Brasileiro de classificação de solos. 2. ed. Brasília: Embrapa Spi, 2006. Disponível em: http:/www.agrolink.com.br/downloads/ sistema-brasileiro-de-classificacao-dos-solHYY;os2006. pdf $>$. Acesso em: 2 jun. 2015.

FAINE, S.; ADLER, B.; BOLIN, C.; PEROLAT, P. Leptospira and Leptospirosis. $2^{\text {th }}$ ed. Melbourne: MedSci, 1999. $272 \mathrm{p}$.

FELT, S. A.; WASFY, M. O.; EL-TRAS, W. F.; SAMIR, A.; RAHAMAN, B. A.; BOSHRA, M.; PARKER, T. M.; HATEM, M. E.; EL-BASSIOUNY, A. A.; MURRAY, C. K.; PIMENTEL, G. Cross-species surveillance of Leptospira in domestic and peri-domestic animals in Mahalla city, Gharbeya Governorate, Egypt. The American Journal of Tropical Medicine and Hygiene, Baltimore, v. 84, n. 3, p. 420-425, 2011.

FONZAR, U. J. V.; LANGONI, H. Geographic analysis on the occurrence of human and canine leptospirosis in the City of Maringá, State of Paraná, Brazil. Revista da Sociedade Brasileira de Medicina Tropical, Rio de Janeiro, v. 45, n. 1, p. 100-105, 2012.

FORSTER, K. M.; HARTWIG, D. D.; SEIXAS, F. K.; MCBRIDE, A. J. A.; MONTE, L. G.; RECUERO, A. L. C.; BROD, C. S.; HARTLEBEN, C. P.; AMARAL, M.; DELLAGOSTIN, O. A. Characterization of a virulent Leptospira interrogans strain isolated from an abandoned swimming pool. Brazilian Journal of Microbiology, Rio de Janeiro, v. 44, n. 1, p. 165-170, 2013.

GAROUSSI, M. T.; VAND-E-USEEFEE, J.; MEHRZAD, J. Seroprevalence of Leptospiral infection in rodents of dairy cattle herds complexes in suburb of Mashhad - Iran. Journal of Applied Animal Research, Janakpuri, v. 30, n. 2, p. 109-111, 2006.

GERÔNIMO, E.; GONCALVES, D. D.; SILVA, A. V. da; EVERS, F.; NINO, B. S. L.; VON SOHSTEN, A. L.; NAVARRO, I. T.; FREIRE, R. L.; MOURA, R. A.; LOPES-MORI, F. R. Anti-Leishmania spp. antibodies in stray dogs housed in a private shelter in the Northwest Region of Parana State, Brazil. African Journal of Microbiology Research, Nigéria, v. 8, n. 20, p. 19951999, 2014.

GONÇALVES, A. T. S. Leptospirose em São Miguel: caracterização dos primeiros isolados humanos de Leptospira sp. e diferenciação molecular de estirpes isoladas dos principais reservatórios silváticos. 2009. Dissertação (Mestrado em Microbiologia Clínica) Universidade de Lisboa, Lisboa.

GONÇALVES, D. D.; BENITEZ, A.; LOPES-MORI, F. M. R.; ALVES, L. A.; FREIRE, R. L.; NAVARRO, I. T.; SANTANA, M. A. Z.; SANTOS, L. R. A.; CARREIRA, T.; VIEIRA, M. L. J.; FREITAS, J. C. de. Zoonoses in humans from small rural properties in Jataizinho, Paraná, Brazil. Brazilian Journal of Microbiology, Rio de Janeiro, v. 44, n. 1, p. 125-131, 2013.

HALLIDAY, J. E. B.; KNOBEL, D. L.; ALLAN, K. J.; BRONSVOORT, B. M.C.; HANDEL, I.;AGWANDA, B.; CUTLER, S.; OLACK, B.; AHMED, A.; HARTSKEERL, R. A.; NJENGA, M. K.; CLEAVELAND, S.; BREIMAN, R. F. Urban Leptospirosis in Africa: a cross-sectional survey of Leptospira infection in the Kibera urban settlement, Nairobi, Kenya. The American Journal of Tropical Medicine and Hygiene, Baltimore, v. 89, n. 6, p. 1095-1102, 2013.

HARTSKEERL, R. A.; COLLARES-PEREIRA, M.; ELLIS, W. A. Emergence, control and re-emerging leptospirosis: dynamics of infection in the changing world. Clinical Microbiology and Infection, Paris, v. 17, n. 4, p. 494-501, 2011.

HERRMANN, D. C.; MAKSIMOV, P.; MAKSIMOV, A.; SUTOR, A.; SCHWARZ, S.; JASCHKE, W.; SCHLIEPHAKE, A.; DENZIN, N.; CONRATHS, F. J.; SCHARES. G. Toxoplasma gondii in foxes and rodents from the German Federal States of Brandenburg and Saxony-Anhalt: seroprevalence and genotypes. Veterinary Parasitology, Chichester, v. 185, n. 2-4, p. 78$85,2012$.

HIGINO, S. S. S.; AZEVEDO, S. S. Leptospirose em pequenos ruminantes: situação epidemiológica atual no Brasil. Arquivos do Instituto Biológico, São Paulo, v. 81, n. 1, p. 86-94, 2014.

INSTITUTO PARANAENSE DE DESENVOLVIMENTO ECONÔMICO E SOCIAL IPARDES. Relação dos municípios do estado ordenados segundo as mesorregiões e as microrregiões geográficas do IBGE - Paraná. Curitiba: Ipardes, 2012. Disponível em: <http://www.ipardes.gov.br/pdf/mapas/base_fisica/ relacao mun micros mesos parana.pdf $>$. Acesso em: 2 jun. 2015 . 
JITTAPALAPONG, S.; SARATAPHAN, N.; MARUYAMA, S.; HUGOT, J. P.; MORAND, S.; HERBRETEAU, V. Toxoplasmosis in rodents: ecological survey and first evidences in Thailand. Vector-Borne and Zoonotic Diseases, Larchmont, v. 11, n. 3, p. 231-237, 2011.

LANGONI, H.; KURIBARA, I. Y.; CORREA, A. P. F. L.; ULLMANN, S.; SÁNCHEZ, G. P.; LUCHEIS, S. B. Anti-leptospirosis agglutinins in Brazilian capybaras (hydrochoerus hydrochaeris). Journal of Venomous Animals and Toxins including Tropical Diseases, Botucatu, v. 22, n. 4, p. 1, 2016.

LEVETT, P. N. Leptospirosis. Clinical Microbiology Reviews, Washington, v. 14, n. 2, p. 296-326, 2001.

MACIEL, E. A. P.; CARVALHO, A. L. F. de; NASCIMENTO, S. F.; MATOS, R. B. de; GOUVEIA, E. L.; REIS, M. G.; KO, A. I. Household transmission of Leptospira infection in Urban Slum Communities. PLoS Neglected Tropical Diseases, San Francisco, v. 2, n. 1, p. e154, 2008.

MARTINS, G.; LILENBAUM, W. The panorama of animal leptospirosis in Rio de Janeiro, Brazil, regarding the seroepidemiology of the infection in tropical regions. BMC Veterinary Research, London, v. 9, n. 237, p. 1-7, 2013.

MASCOLLI, R.; SOTO, F. R. M.; BERNARDI, F.; ITO, F. H.; PINHEIRO, S. R.; GUILLOUX, A. G. A.; AZEVEDO, S. S.; FERNANDES, A. R. F.; KEID, L. B.; MORAIS, Z. M.; SOUZA, G. O.; VASCONCELLOS, S. A. Prevalência e fatores de risco para a leptospirose e brucelose na população canina da Estância Turística de Ibiúna, São Paulo, Brasil. Arquivos do Instituto Biológico, São Paulo, v. 83, n. 0, p. 1-7, 2016.

MERCIER, A.; GARBA, M.; BONNABAU, H.; KANE, M.; ROSSI, J. P.; DARDÉ, M. L.; DOBIGNY, G. Toxoplasmosis seroprevalence in urban rodents: a survey in Niamey, Niger. Memórias do Instituto Oswaldo Cruz, Rio de Janeiro, v. 108, n. 4, p. 399-407, 2013.

MGODE, G. F.; KATAKWEBA, A. S.; MHAMPHI, G. G.; FWALO, F.; BAHARI, M.; MDANGI, M.; KILONZO, B. S.; MULUNGU, L. S. Prevalence of leptospirosis and toxoplasmosis: a study of rodents and shrews in cultivated and fallow land, Morogoro rural district, Tanzania. Tanzania Journal of Health Research, Dar es Salaam, v. 16, n. 3, p. 1-7, 2014.

MINEIRO, A. L. B. B.; BEZERRA, E. E. A.; VASCONCELLOS, S. A.; COSTA, F. A. L.; MACEDO, N. A. Infecção por leptospira em bovinos e sua associação com transtornos reprodutivos e condições climáticas. Arquivo Brasileiro de Medicina Veterinária e Zootecnia, Belo Horizonte, v. 59, n. 5, p. 1103-1109, 2007.
MOHAMED, H.; BAHAMAN, S. N.; MUTALIB, A. R.; BEJO, A. R.; KHAIRANI, S. Serological prevalence of leptospiral infection in wild rats at the National Service Training Centres in Kelantan and Terengganu. Tropical Biomedicine, Kuala Lumpur, v. 27, n. 1, p. 30-32, 2010.

MORIKAWA, V. M. Leptospirose. In: . Programa de Zoonoses Região Sul: manual de Zoonoses CMRVPR, CRMV-SC, CRMV-RS. 2. ed. Curitiba: [s.n.], 2010. v. 1, 168 p. Disponível em: <http://www.crmvrs.gov.br/ Manual_de_Zoonoses_I.pdf $>$.Acesso em: 4 ago. 2014.

PALANIAPPAN, R. U.; RAMANUJAM, S.; CHANG, Y. F. Leptospirosis: pathogenesis, immunity, and diagnosis. Current Opinion in Infectious Diseases, Hagerstown, v. 20, n. 3, p. 284-292, 2007.

PINTO, L. D.; ARAÚJO, F. A. P.; STOBB, N. S.; MARQUES, S. M. T. Soroepidemiologia de Toxoplasma gondii em gatos domiciliados atendidos em clínicas particulares de Porto Alegre, RS, Brasil. Ciência Rural, Santa Maria, v. 39, n. 8, p. 2464-2469, 2009.

PIZZI, H. L. Toxoplasmosis. Buenos Aires: Rhône Poulenc Rorer Argentina, 1997. 91 p.

PORTA, D.; GONCALVES, D. D.; GERÔNIMO, E.; DIAS, E. H.; MARTINS, L. A.; RIBEIRO, L. V. P.; OTUTUMI, L. K.; MESSA, V.; GERBASI, A. V. Parasites in synanthropic rodents in municipality in the Northwest Region of the State of Paraná, Brazil. African Journal of Microbiology Research, Nigéria, v. 8, n. 16, p. 1684-1689, 2014.

RIEDEMANN, S.; ZAMORA, J.; CABEZAS, X. Leptospirosis in wild rodents captured in Valdivia city. Serological and immunochemical diagnosis. AgroCiencia, Concepcion, v. 10, n. 2, p. 133-138, 1994.

RODRIGUES, T. C. S.; SANTOS, A. L. Q.; LIMARIBEIRO, A. M. C.; LEMOS, F. G.; AZEVEDO, F. C.; ARRAIS, R. C.; GOMES, D. O.; TAVARES, T. C. F. Occurrence of antibodies against Leptospira spp. in free-ranging wild canids from the Brazilian savanna. Pesquisa Veterinária Brasileira, Rio de Janeiro, v. 35, n. 8, p. 734-740, 2015.

ROMERO-VIVAS, C. M.; THIRY, D.; RODRIGUEZ, V.; CALDERÓN, A.; ARRIETA, G.; MÁTTAR, S.; CUELlO, M.; LEVETT, P. N.; FALCONAR, A. K. Molecular serovar characterization of Leptospira isolates from animals and water in Colombia. Biomédica, Bogotá, v. 33, n. 1, p. 179-184, 2013.

ROSEGHINI, W. F. F.; NERY, J. T.; MARTINS, M. L. O. Variabilidade sazonal da precipitação na região Noroeste do Paraná. In: CONGRESSO BRASILEIRO DE METEOROLOGIA, 11, 2000, Rio de Janeiro. Anais... Rio de Janeiro: SBMet, 2000, p. 837-846. 
Disponível em: http://www.cbmet.com/edicoes.php? pageNum_Recordset_busca=10\&totalRows_Recordset_ busca $=551$ \&cgid $=12 \&$ imageField $2 . x=43 \&$ imageField 2 . $\mathrm{y}=7$. Acesso em: 01 nov. 2014.

RUFFOLO, B. B. Toxoplasma gondii e enteroparasitoses em ratos urbanos capturados em locais de reciclagem de Resíduos Sólidos na Cidade de Londrina - PR. 2008. Dissertação (Mestrado em Ciência Animal) Universidade Estadual de Londrina, Londrina.

SAMIR, A.; SOLIMAN, R. K.; EL-HARIRI, M.; ABDEL-MOEIN, K.; HATEM, M. E. Leptospirosis in animals and human contacts in Egypt: broad range surveillance. Revista da Sociedade Brasileira de Medicina Tropical, Rio de Janeiro, v. 48, n. 3, p. 272277, 2015.

SANTA ROSA, C. A.; SULZER, C. R.; YANAGUITA, R. M.; SILVA, A. S. Leptospirose em animais selvagens no Brasil: o isolamento de canicola sorovares, pyrogenes e grippotyphosa. International Journal of Zoonoses, Taipei, v. 7, n. 1, p. 40-43, 1980.

SISTEMA DE INFORMAÇÃO DE AGRAVOS DE NOTIFICAÇÃO - SINAN. Leptospirose - óbitos por Leptospirose. Brasil, grandes regiões e unidades federadas. 2000 a 2016. Brasília: [s.n.], c2016. Disponível em: $<$ http://portalsaude.saude.gov.br/index.php/situacaoepidemiologica-dados $>$. Acesso em: 22 ago. 2016.

SOCOLOVSCHI, C.; ANGELAKIS, E.; RENVOISÉ, A.; FOURNIER, P. E.; MARIÉ, J. L.; DAVOUST, B.; STEIN, A.; RAOULT, D. Strikes, flooding, rats, and leptospirosis in Marseille, France. International Journal of Infectious Diseases, Hamilton, v. 15, n. 10, p. 710-715, 2011.
SPOHR, K. A. H. Leptospirose em ratos urbanos em Londrina, Paraná. 2009. Dissertação (Mestrado em Ciência Animal) - Universidade Estadual de Londrina, Londrina.

TOMÉ, L. H. P.; LIMA, J. F. de. O desenvolvimento humano nos municípios da mesorregião Noroeste Paranaense. Revista Eletrônica do Programa de PósGraduação de Geografia - UFPR, Curitiba, v. 9, n. 1, p. 99-116, 2014.

VASCONCELLOS, S. A.; BARBARINI JÚNIOR, O.; UMEHARA, O.; MORAIS, Z. M.; CORTEZ, A.; PINHEIRO, S.R.; FERREIRA, F.; FÁVERO, A. C. M.; FERREIRA NETO, J. S. Leptospirose bovina. Níveis de ocorrência e sorotipos predominantes em rebanhos dos Estados de Minas Gerais, São Paulo, Rio de Janeiro, Paraná, Rio Grande do Sul e Mato Grosso do Sul no período de janeiro a abril de 1996. Arquivos do Instituto Biológico, São Paulo, v. 64, n. 2, p. 7-15, 1997.

VUJANIĆ, M.; IVOVIĆ, V.; KATARANOVSKI, M.; NIKOLIĆ, A.; BOBIĆ, B.; KLUN, I.; VILLENA, I.; KATARANOVSKI, D.; DJURKOVIĆ-DJAKOVIĆ, O. Toxoplasmosis in naturally infected rodents in Belgrade, Serbia. Vector Borne and Zoonotic Diseases, Larchmont, v. 11, n. 8, p. 1209-1211, 2011.

WANG, C.; HE, H. Leptospira spp. in commensal rodents, Beijing, China. Journal of Wildlife Diseases, Ames, v. 49, n. 2, p. 461-463, 2013.

WASIŃSKI, B.; DUTKIEWICZ, J. Leptospirosis current risk factors connected with human activity and the environment. Annals of Agricultural and Environmental Medicine, Lublin, v. 20, n. 2, p. 239-244, 2013. 